\title{
IMPLEMENTASI AUDIT MUTU INTERNAL ISO 9001 PADA SISTEM MANAJEMEN RSUD KAYU AGUNG KABUPATEN OKI
}

\author{
Septiani Fransisca \\ Sabeli Aliya \\ Universitas Bina Darma Palembang \\ septiani.fransisca@binadarma.ac.id \\ sably@binadarma.ac.id
}

\begin{abstract}
Many companies have implemented ISO 9001 but no research has focused on the factors that made up the internal audit quality variables. This research took place at the Rumah Sakit Umum Daerah of Kayu Agung of Ogan Komering Ilir Regency. This research used quantitative descriptive method. The population was stakeholders related to the entity, the sample used cluster sampling and simple random sampling. The data used primary data derived from the dispersed questionnaire. The distribution of questionnaire was conducted in 2018. The technique of data analysis used validity test, profitability test, and normality test. In analyzing the researchers used simple linear regression analysis. The calculation results showed the value of $R$ Square was 0.629. This meant that 62.9\% of the Kayu Agung Hospital Management System in Ogan Komering Ilir Regency was influenced by the ISO 9001 Internal Quality Audit.
\end{abstract}

Keywords: Internal quality audit, ISO 9001, Management system.

\section{PENDAHULUAN}

Laju arus globalisasi yang kian cepat dan padat ini, menyebabkan kebutuhan manusia menjadi semakin beragam serta kompleks sifatnya. Berbagai hal bisa saja tersaji dengan cepat (instant), namun tetap terkendali. Artian terkendali di sini adalah adanya pengaturan yang baik serta profesional di belahan bumi manapun. Menelaah hal ini maka dibutuhkan standar baku atau layanan terpadu yang mampu menghasilkan produk dan jasa seragam serta bisa difungsikan dimana pun keberadaan kita. Standar baku universal inilah yang kemudian disebut ISO. Merupakan kepanjangan dari International Organization for Standardization (Suryatama, $2014: 4$ ).

Strategi dalam persaingan dewasa ini terletak pada kualitas yang ditawarkan dalam produk/jasa. Umumnya para pesaing akan berlomba menawarkan sesuatu yang relatif lebih tinggi kualitasnya namun tetap memiliki harga yang relatif tidak tinggi. Hal ini bisa menjadi sumber peningkatan laba perusahaan. Jika salah langkah, 
peningkatan kualitas akan menjadi masalah bagi perusahaan, diantaranya adalah pemborosan biaya. Produk yang biasa saja/standar rendah akan membutuhkan effort yang tidak sedikit sehingga bisa bertransformasi menjadi produk berkualitas. Karenanya, penyebab pemborosan perusahaan adalah produk yang berkualitas rendah (Bayangkara, $2016: 26$ ).

Penerapan Sistem Manajemen Mutu di Indonesia telah memberikan dampak yang baik bagi semua jenis entitas yang ada di Indonesia. Peningkatan mutu tak jarang menjadi prasyarat dalam penilaian baik oleh pemerintah maupun pengguna. Jaminan mutu kualitas produk maupun jasa dalam negeri diperoleh dari penerapan sistem mutu secara berkesinambungan. Peran auditor melalui audit internal sangat dibutuhkan untuk menjaga keberlangsungan kualitas entitas.

Audit sangat bermanfaat bagi entitas untuk menjaga konsistensinya terhadap efisiensi serta efektifitas yang selama ini telah berhasil diraih, baik entitas dalam sektor komersil maupun entitas dalam sektor publik. Melalui audit diketahui sampai sejauh mana para penanggung jawab di entitas harus bekerja sesuai dengan ketentuan kerja, standar yang ditetapkan, prosedur dan instruksi kerja yang nyata. Selain itu juga harus memenuhi kondisi lingkungan kerja yang harus dipatuhi dan disiplin terhadap dokumen-dokumen yang digunakan. Karena audit memiliki prinsip bahwa pengecekan terhadap auditi harus memberikan bukti-bukti yang nyata (Priyadi, 2012 : 2).

Adanya penerapan ISO 9001disinyalir dapat meminimalkan risiko pada lingkungan Rumah Sakit Umum Daerah Kayu Agung Kabupaten Ogan Komering Ilir. Selain itu, sebagai salah satu instansi pemerintah yang menjadi andalan masyarakat Kabupaten Ogan Komering Ilir, maka RSUD Kayu Agung berbenah diri dengan mengikuti sertifikasi ISO 9001demi meningkatkan pelayanan kepada masyarakat. ISO 9001dianggap mampu memperbaiki bukan hanya dari internal tetapi juga bagi pihak eksternal. RSUD Kayu Agung beruapaya meningkatkan akreditasi dari tipe C Plus menjadi tipe B pada tahun 2018. Karena itulah, sangat menarik untuk mengetahui bagaimana analisis faktor audit mutu internal ISO 9001pada RSUD Kayu Agung Kabupaten Ogan Komering Ilir dengan cara audit internal. Untuk memastikan juga kualitas ISO 9001 yang mereka implementasikan dalam kaitannya menuju akreditasi tipe B. 
Tujuan instansi menuju Akreditasi tipe B pada tahun 2018 tidak bisa terlepas dari sertifikasi ISO 9001 yang telah didapatkan oleh pihak Rumah Sakit. Apa yang menjadi fokus dalam proses penilaian ISO 9001 juga menjadi fokus perhatian dalam proses mendapatkan akreditasi tipe B pada tahun 2018. Penulis meyakini bahwa hasil penelitian ini dapat menjadi rekomendasi apakah ISO 9001 telah diterapkan dengan baik dan dirasakan pada semua lini.

Agar tidak menyimpang jauh dari permasalahan diatas, maka disini peneliti membatasi permasalahan hanya yang terkait dengan analisis faktor Audit Mutu Internal ISO 9001pada RSUD Kayu Agung Kabupaten Ogan Komering Ilir dengan pendekatan terhadap proses entitas yang ada, manajemen kepemimpinannya, SDM yang terlibat, pelanggan menjadi fokus utama, kepemimpinan, keterlibatan sumber daya manusia, pendekatan proses, perbaikan yang berkelanjutan, pembuatan keputusan berdasarkan fakta, serta hubungan dengan pemangku kepentingan.

\section{TINJAUAN PUSTAKA}

\section{Teori Signalling}

Teori ini menjelaskan bahwa pihak manajemen dapat mengantisipasi kesalahan dalam penyampaian informasi (asimetri informasi) kepada semua pihak. Pihak manajemenlah yang mengetahui kondisi keuangan dan prospek perusahaan yang sebenarnya. Catatan akrual diskresioner dapat memberikan sinyal bagi pihak eksternal. Jika pada kondisi keuangan serta prospek perusahaan dalam kondisi prima maka pihak manajemen dapat memberikan catatan akrual diskresioner yang positif. Sebaliknya jika kondisi keuangan serta prospek perusahaan dalam kondisi buruk maka pihak manajemen dapat memberikan catatan negatif. Hal ini dapat menunjukkan sisi integritas sebuah entitas, serta memiliki keyakinan dalam mengatasi semua permasalahan yang muncul (Lo, 2012 : 2).

\section{Definisi ISO}

Bahasa Yunani menjelaskan definisi dari ISO. Isos diartikan 'sama', atau dalam Bahasa Inggris dinamakan 'equal'. Penggunaan kata 'iso' sering menjadi awal dari sebuah kata dalam Bahasa Indonesia. Contohnya "isonomy", "isometric", "isomer", dan lainnya. Sebagian orang berpikir ada kecanggungan mengenai "International Organization for Standardization' dengan kependekannya 'IOS'. Namun kebanyakan 
orang lain menyingkat ISO.Mungkin dapat kita anggap tepat jika hal tersebut adalah kependekan atau singkatan. Akhirnya, sebutan ISO bukan lagi suatu kependekan, tetapi merupakan nama sebuah organisasi berkelas internasional (Suryatama, 2014 : $10)$.

Kata ISO diambil dengan maksud tertentu. Tujuannya adalah sebagai bentuk penghindaran penyingkatan bila diterjemahkan oleh negara-negara anggota ISO. Hal ini menjadi satuan organisasi berkelas internasional. Contoh saja, jika di negara Prancis, ISO menjadi OIN (Organisation Internationale de Normalisation). Sedangkan jika di negara Inggris akan berubah menjadi IOS. Bahkan di Indonesia sendiri bisa berubah menjadi OSI (Organisasi Standardisasi Internasional). Karena itulah, sebutan ISO yang digunakan apapun Bahasa yang dipakai, serta apapun negaranya. Jadi ISO bisa dirangkum sebagai standar kerja internasional yang terkoordinasi, standar harmonisasi internasional yang terpublikasi, serta promosi pemakaian standar internasional (Suryatama, $2014: 11$ ).

\section{ISO 9001}

Quality Management System dengan definisinya Sistem Penjaminan Mutu sering disebut juga sebagai ISO 9001. Standar ini disusun, disetujui, dan diimplementasi oleh entitas tertentu guna menjalankan operasional usahanya. Urutan terbaik dalam operasional perusahaan juga diatur dalam sistem ISO 9001. Urutan satu aktivitas yang kemudian akan dilanjutkan ke aktivitas lainnya. Juga dijelaskan bagaimana suatu peristiwa ekonomi perusahaan dimulai dari konsumennya, kemudian dimasukkan dalam input, lalu diproses, dan pada akhirnya menghasilkan output. Ukuran fisik yang digunakan untuk menilai hasil pekerjaan karyawan, serta menentukan apakah hasil tersebut memenuhi standar kualitas yang ditentukan oleh entitas. Standar ISO 9001 tidak bisa hanya menjjiplak prosedur yang sudah ada. Manfaat dapat diraih perusahaan jika perusahaan melakukan proses semaksimal mungkin serta komitmen dari seluruh pihak manajemen yang terjaga (Suryatama, 2014 : 15).

\section{Manfaat Standar Internasional}

Berikut ini merupakan manfaat-manfaat yang dapat dirasakan entitas jika menerapkan Standar Internasional menurut Suryatama (2014:14): Perluasan pangsa pasar, diharapkan produktivitas akan bertambah melalui standar internasional yang 
digunakan serta menambah keunggulan kompetitif entitas; Lingkungan menjadi lebih terlindungi serta terjaga dengan penggunaan standar internasional ini; Efisiensi biaya entitas yang berguna dalam optimalisasi kegiatan entitas sehari-hari; Hambatan dalam hal perdagangan akan dapat dihindari, sehingga membuka peluang pasar global yang lebih besar, dengan kata lain akses ke pangsa pasar yang belum terjamah akan lebih luas lagi; Dan yang terpenting adalah kepuasan konsumen mengenai kualitas produk barang ataupun jasa sehingga akan berdampak pada meningkatnya pendapatan perusahaan.

\section{ISO 9001}

Menurut Bayangkara (2016:26) standar ini mendasarkan Manajemen Kualitas pada 7 (tujuh) prinsip manajemen kualitas yang terdiri atas: Orientasi terpusat pada Pelanggan; Proses melalui pendekatan; Sumber Daya Manusia yang terlibat; Kepemimpinan; Selalu melakukan perbaikan; Bukti yang ada sebagai dasar dalam Pembuatan Keputusan; Pihak-pihak yang berkepentingan saling menghubungkan satu dengan lainnya.

\section{Audit}

Audit didefinisikan sebagai pemeriksaan oleh pihak eksternal yang independen mengenai laporan keuangan yang sudah disusun oleh pihak perusahaan (manajemen) berikut juga semua catatan-catatan pelaporan, serta bukti-bukti yang mendukung, pemeriksaan tentu saja dilakukan secara kritis, dengan maksud agar menghasilkan opini (pendapat) mengenai wajar atau tidaknya laporan keuangan yang disajikan (Agoes, $2014:$ 10).

Proses berurutan (sistematik) guna mendapatkan serta menindaklanjuti temuan bukti secara objektif tentang kejadian ekonomi dan pernyataan-pernyataan untuk mengukur kesesuaian antara kriteria yang ada dikaitkan dengan pernyataanpernyataan yang dibangun, serta kepentingan para stakeholders untuk mengetahui hasilnya dinamakan juga audit (Mulyadi, 2016:50).

\section{HIPOTESIS}

Ho : Tidak ada pengaruh antara Audit Mutu Internal ISO 9001terhadap Sistem Manajemen RSUD Kayu Agung Kabupaten Ogan Komering Ilir. 
Ha : Ada pengaruh antara Audit Mutu Internal ISO 9001terhadap Sistem Manajemen RSUD Kayu Agung Kabupaten Ogan Komering Ilir

\section{METODE PENELITIAN}

Metode yang dipakai dalam penelitian ini yaitu metode deskriptif kuantitatif.Data penelitiannya berupa angka-angka dan kemudian dianalisis menggunakan statistik (Sugiyono, 2014 : 33). Populasi dalam penelitian ini adalah stakeholders (pihak-pihak yang berkepentingan) pada RSUD Kayu Agung Kabupaten Ogan Komering Ilir. Populasi dapat berasal dari manajemen Rumah Sakit, Tenaga Medis, Tenaga Non Medis, Pasien, Masyarakat, pihak instansi lain, dsb. Sedangkan sampel dalam penelitian menggunakan dua teknik sampling. Pertama menggunakan Cluster Sampling (Sampling Area) terhadap lingkungan Rumah Sakit yang cukup besar. Sehingga responden diambil dari perwakilan masing-masing bagian yang ada di Rumah Sakit. Setelah di Cluster Sampling, peneliti kemudian menggunakan Simple Random Sampling (Sampling Acak Sederhana) maksudnya ketika peneliti telah ke Bagian Poli tertentu yang ada pada Rumah Sakit, maka siapapun pihak Stakeholders yang bersedia mengisi kuisioner akan dipersilahkan untuk mengisi kuisioner hingga jumlah kuisioner dirasa cukup mewakili dari bagian tersebut (Sugiyono, $2014: 40$ ).

\section{Sumber Data}

Pengumpulan data yang langsung dilakukan oleh peneliti terhadap sumber data dinamakan data primer (Sugiyono, 2014 : 20). Penelitian ini didukung oleh data primer dengan menggunakan beberapa teknik pengumpulan data. Pertama, peneliti melakukan wawancara pada bagian terkait, kemudian menyebarkan kuisioner kepada sampel yang dituju. Penyebaran kuisioner berfokus pada faktor-faktor Audit Mutu Internal ISO 9001. Tipe pengisian kuisioner adalah Self Administrated Questionnaire, dimana kuisioner diisi sendiri oleh subjek penelitian. Dalam hal ini adalah pihak Stakeholders yang terkait dengan RSUD Kayu Agung Kabupaten Ogan Komering Ilir.

\section{Teknik Analisis Data}

Metode analisis data dalam penelitian ini dilakukan dalam beberapa tahap. Pertama, peneliti akan menguji daftar pertanyaan atau kuisioner dengan 
menggunakan alat uji Validitas dan Uji Reliabilitas.Data-data yang didapatkan hasil kuisioner kemudian akan diuji normalitasnya menggunakan Uji Normal KolmogorovSmirnov. Uji normalitas data ini lebih layak dilakukan sebelum data diolah berdasarkan model penelitian. Tujuan utama dalam Uji normalitas agar kita mengetahui distribusi sebaran data dalam variabel penelitian yang kita telah lakukan. Sebaik-baik data yang dapat dipakai dalam penelitian, merupakan data yang berdistribusi normal.Terakhir permodelan akan dianalisis menggunakan analisis regresi sederhana (Sujarweni, $2016: 83$ ).

\section{HASIL PENELITIAN}

Penelitian ini dilakukan melalui berbagai tahapan proses. Tahap ini dinamakan juga tahap uji coba alat ukur. Berikutnya akan dilakukan uji validitas serta uji reliabilitas. Program SPSS versi 20,0 atau dinamakan juga Statistical Package for Social Science adalah tool yang membantu dalam proses analisis penelitian, termasuk di dalamnya uji validitas, uji reliabilitas dan uji lanjutan lainnya. Perihal cara pengujian yang memanfaatkan daftar pertanyaan (kuisioner) agar dapat dijawab oleh responden serta dinyatakan layak atau tidaknya dalam pelengkapan pengambilan data penelitian, maka sangat dianjurkan untuk melakukan uji validitas dan reliabilitas (Sujarweni, 2016 :50).

\section{Uji Validitas}

Tahapan uji yang pertama dilakukan adalah uji validitas.Alat uji ini sangat berguna jika menggunakan kuisioner dalam mendapatkan data penelitian. Layak atau tidak setiap pertanyaan yang disajikan dalam kuisioner akan terjawab jika menggunakan uji validitas. Sehingga pertanyaan-pertanyaan yang muncul dianggap mampu mewakili suatu variabel. Banyaknya pertanyaan dibangun untuk men-support variabel kelompok tertentu. Tidak disarankan jika uji ini dilakukan secara bersamaan terhadap semua butir pertanyaan. Akan lebih valid jika setiap pertanyaan diuji secara terpisah. Pembandingan antara $r$ hitung dengan $r$ tabel melihat letak $\mathrm{df}=\mathrm{n}-2$ dengan nilai signifikansi tertentu. Penelitian ini menggunakan tingkat signifikansi 5\%. R tabel yang lebih besar dari $r$ hitung menunjukkan hasil analisa yang valid. 
Tabel Uji Validitas

Case Processing Summary

\begin{tabular}{|rl|r|r|}
\hline & & N & \multicolumn{1}{|c|}{$\%$} \\
\hline & Valid & 93 & 100.0 \\
Fases & Excluded & & \\
& a & 0 & .0 \\
& Total & 93 & 100.0 \\
\hline
\end{tabular}

a. Listwise deletion based on all

variables in the procedure.

(Sumber: data diolah SPSS, 2018)

Dengan melihat tabel $\mathrm{r}$ product moment Pearson, menunjukkan bahwa df (degree of freedom $)=\mathrm{n}-2$, maka diketahui nilai $\mathrm{df}=93-2$. Nilai 93 didapatkan berdasarkan jumlah penjawab kuisioner (responden). Besaran signifikansi yang digunakan untuk menganalisanya sebesar $5 \%$, dikaitkan dengan $r$ tabel senilai 0,172 . Setiap pertanyaan yang diuji akan dikatakan lulus uji validitas jika $r$ hitung $>r$ tabel. Nilai $r$ hitung akan tampak pada tabelCorrected Item Total Correlation. Hasil output tergambar pada tabel di bawah ini:

Tabel Perbandingan R Hitung dengan R Tabel

\begin{tabular}{|l|r|r|c|}
\hline Variabel & R hitung & R tabel & Keterangan \\
\hline P1 & 0.722 & 0.172 & Valid \\
P2 & 0.747 & 0.172 & Valid \\
P3 & 0.426 & 0.172 & Valid \\
P4 & 0.517 & 0.172 & Valid \\
P5 & 0.804 & 0.172 & Valid \\
P6 & 0.619 & 0.172 & Valid \\
P7 & 0.638 & 0.172 & Valid \\
P8 & 0.722 & 0.172 & Valid \\
P9 & 0.704 & 0.172 & Valid \\
P10 & 0.377 & 0.172 & Valid \\
\hline
\end{tabular}




\begin{tabular}{|l|l|l|l|} 
P11 & 0.565 & 0.172 & Valid \\
P12 & 0.550 & 0.172 & Valid \\
P14 & 0.750 & 0.172 & Valid \\
P15 & 0.610 & 0.172 & Valid \\
P16 & 0.567 & 0.172 & Valid \\
P17 & 0.707 & 0.172 & Valid \\
P18 & 0.758 & 0.172 & Valid \\
P19 & 0.483 & 0.172 & Valid \\
P20 & 0.573 & 0.172 & Valid \\
P21 & 0.598 & 0.172 & Valid \\
P22 & 0.791 & 0.172 & Valid \\
P23 & 0.577 & 0.172 & Valid \\
P24 & 0.655 & 0.172 & Valid \\
P25 & 0.707 & 0.172 & Valid \\
P26 & 0.778 & 0.639 & Valid \\
P27 & 0.595 & 0.172 & Valid \\
P28 & 0.551 & 0.172 & Valid \\
P29 & 0.630 & 0.172 & Valid \\
P30 & 0.496 & 0.172 & Valid \\
P31 & 0.552 & 0.172 & Valid \\
P32 & P33 & 0.172 & Valid \\
P34 & P35 & 0.172 & Valid \\
\hline & 0.172 & Valid \\
P2 & 0.172 & Valid \\
\hline
\end{tabular}

(Sumber: data diolah SPSS, 2018)

Pertanyaan P1 hingga P26 mewakili Variabel Audit ISO 9001 sebagai variabel dependen dalam penelitian ini. Dari tabel di atas menunjukkan bahwa semua pertanyaan valid dan dapat digunakan dalam penelitian. Begitu pula dengan P27 hingga P35 mewakili Variabel Sistem Manajemen menunjukkan bahwa semua pertanyaan valid dan dapat digunakan dalam penelitian selanjutnya. 


\section{Uji Reliabilitas}

Uji reliabilitas adalah tahapan uji berikutnya yang harus dilakukan. Keandalan dapat terukur melalui uji reliabilitas ini. Uji ini juga berguna untuk mengukur kestabilan dalam menjawab perihal tentang bentuk-bentuk pertanyaan, selain itu juga dapat mengukur konsistensi penjawab pertanyaan (responden). Hal ini juga dapat menjadi dimensi variabel yang tersusun dalam pertanyaan terstruktur (kuisioner). Uji reliabilitas terhadap semua pertanyaan yang ada bisa dilakukan bersamaan tanpa harus menguji secara terpisah seluruh butir pertanyaannya. Berikut ini merupakan data hasil uji reliabilitas:

\section{Tabel Uji Reliabilitas}

Reliability Statistics

\begin{tabular}{|r|r|}
\hline $\begin{array}{c}\text { Cronbach's } \\
\text { Alpha }\end{array}$ & \multicolumn{1}{c|}{$\begin{array}{c}\mathrm{N} \text { of } \\
\text { Items }\end{array}$} \\
\hline .959 & 35 \\
\hline
\end{tabular}

(Sumber: data diolah SPSS, 2018)

Jika nilai Alpha > 0,70 maka reliabel. Melihat hasil dari perhitungan uji reliabiltasnya menunjukkan bahwa nilai Cronbach's Alpha sebesar 0,959 > 0,70. Hal ini berarti semua pertanyaan dalam kuesioner dinyatakan reliabel sebagai pertanyaan dalam penelitian.

\section{Uji Normalitas}

Tahapan sebelum fokus pada model penelitian maka sebaiknya melakukan tahap uji normalitas data.Manfaat dari uji ini adalah berguna untuk mendapatkan informasi terkait distribusi data yang ada di dalam variabel penelitian.Dikatakan data tersebut layak serta baik jika data tersebut mempunyai hasil uji normalitas yang menunjukkan bahwa data penelitian berdistribusi normal.Uji Kolmogorov-Smirnov bisa digunakan sebagai salah satu alat uji untuk melihat sebaran data berdistribus normal atau tidak(Sujarweni, 2016). Dalam penelitian ini data telah diuji normalitasnya dan mendapatkan hasil sebagai berikut: 
Tabel Uji Normalitas

One-Sample Kolmogorov-Smirnov Test

\begin{tabular}{|ll|r|r|}
\hline & & \multicolumn{1}{|c|}{ x } & \multicolumn{1}{c|}{ y } \\
\hline N & Mean & 93 & 93 \\
Normal Parametersat, & Std. & 66.29 & 26.92 \\
& Deviation & 21.053 & 5.939 \\
& Absolute & .127 & .128 \\
Most Extreme & Positive & .097 & .084 \\
Differences & Negative & -.127 & -.128 \\
& & 1.225 & 1.233 \\
Kolmogorov-Smirnov Z & .099 & .096 \\
Asymp. Sig. (2-tailed) & &
\end{tabular}

a. Test distribution is Normal.

b. Calculated from data.

(Sumber: data diolah SPSS, 2018)

Dari hasil perhitungan menggunakan one-sample Kolmogorov-Smirnov Test menunjukkan bahwa Sig data untuk variabel x (Audit ISO 9001) adalah sebesar 0.099 maka lebih besar dari 0.005 sehingga sebaran data dikatakan normal. Sedangkan variabel y (Sistem Manajemen) adalah sebesar 0.096 juga lebih besar dari 0.005 sehingga dapat dikatakan bahwa semua data berdistribusi normal. Hal ini membuat peneliti dapat melakukan uji analisis ke tahap berikutnya.

\section{Uji Regresi Linier Sederhana}

Ada tujuan penting dalam regresi, diantaranya adalah untuk mengetahui pengaruh hubungan antara satu variabel dengan variabel lainnya. Variabel tergantung/terikat merupakan variabel yang dipengaruhi, bernama lain variabel dependen. Dan untuk variabel bebas dinamakan juga variabel independen adalah variabel yang mempengaruhi variabel lainnya (Sujarweni, 2016).Penelitian ini menggunakan permodelan sebagai berikut: $Y=a+b X+$ e. Berikut merupakan hasil 
perhitungan antara variabel dependen (Audit ISO 9001) dengan variabel independen (Sistem Manajemen).

Tabel Uji Regresi

Model Summary

\begin{tabular}{|l|r|r|r|r|}
\hline Model & \multicolumn{1}{|c|}{$\mathrm{R}$} & R Square & $\begin{array}{c}\text { Adjusted R } \\
\text { Square }\end{array}$ & $\begin{array}{r}\text { Std. Error of } \\
\text { the Estimate }\end{array}$ \\
\hline 1 & $.793 \mathrm{a}$ & .629 & .624 & 12.901 \\
\hline
\end{tabular}

a. Predictors: (Constant), y

(Sumber: data diolah SPSS, 2018)

Tabel Anova

ANOVA *

\begin{tabular}{|c|c|c|c|c|c|c|}
\hline \multicolumn{2}{|c|}{ Model } & $\begin{array}{l}\text { Sum of } \\
\text { Squares }\end{array}$ & df & $\begin{array}{l}\text { Mean } \\
\text { Square }\end{array}$ & $\mathrm{F}$ & Sig. \\
\hline \multirow{3}{*}{1} & Regression & 25630.278 & 1 & 25630.278 & 154.003 & $.000^{b}$ \\
\hline & Residual & 15144.883 & 91 & 166.427 & & \\
\hline & Total & 40775.161 & 92 & & & \\
\hline
\end{tabular}

a. Dependent Variable: $x$

b. Predictors: (Constant), y

(Sumber: data diolah SPSS, 2018)

Tabel Koefisien

Coefficients ${ }^{a}$

\begin{tabular}{|c|c|c|c|c|c|}
\hline \multirow[t]{2}{*}{ Model } & \multicolumn{2}{|c|}{$\begin{array}{c}\text { Unstandardized } \\
\text { Coefficients }\end{array}$} & \multirow{2}{*}{$\begin{array}{c}\begin{array}{c}\text { Standardized } \\
\text { Coefficients }\end{array} \\
\text { Beta }\end{array}$} & \multirow[t]{2}{*}{$\mathrm{t}$} & \multirow[t]{2}{*}{ Sig. } \\
\hline & B & Std. Error & & & \\
\hline $\begin{array}{l}\text { (Constant } \\
\text { ) }\end{array}$ & -9.385 & 6.243 & & -1.503 & .136 \\
\hline $\mathrm{y}$ & 2.811 & .226 & .793 & 12.410 & .000 \\
\hline
\end{tabular}

a. Dependent Variable: $x$

(Sumber: data diolah SPSS, 2018) 
Jika melihat dari Sig hasilnya 0.000 kurang dari 0.005 maka didapati hasil Ho ditolak. Maka dapat disimpulkan bahwa ada pengaruh antara Audit Mutu Internal ISO 9001terhadap Sistem Manajemen RSUD Kayu Agung Kabupaten Ogan Komering Ilir. Setelah mengetahui ada pengaruh antara Audit Mutu Internal ISO 9001terhadap Sistem Manajemen RSUD Kayu Agung Kabupaten Ogan Komering Ilir dapat dilihat dari output b yaitu sebesar 2.811 jadi persamaan regresinya adalah:

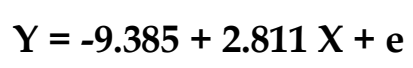

Apabila Audit mutu Internal ISO 9001 meningkat satu satuan maka Sistem Manajemen akan naik sebesar 2.811 .

Nilai $R$ Square dapat juga disebut sebagai koefisien determinasi. Dari hasil perhitungan menunjukkan nilai $R$ Square sebesar 0.629. Hal ini berarti sebesar $62.9 \%$ Sistem Manajemen RSUD Kayu Agung Kabupaten Ogan Komering Ilir dipengaruhi oleh Audit Mutu Internal ISO 9001. Telah terbukti bahwa banyak entitas menggunakan ISO 9001 dalam penerapan sistem manajemennya (Bayangkara, 2016 : 31). Penelitian ini mendukung teori yang dikembangkan oleh Bayangkara (2016 : 24). ISO 9001sebagai standar untuk mengembangkan sistem manajemen kualitasnya dimana akan terintegrasi ke dalam strategi bisnis entitas itu sendiri. Penerapan standar ini sangat membantu tercapainya tujuan strategi bisnis perusahaan. Hal ini berarti bahwa telah terjadi peningkatan nilai tambah terhadap Sistem Manajemen Kualitas RSUD Kayu Agung Kabupaten Ogan Komering Ilir.

Hasil penelitian ini juga mendukung penelitian sebelumnya (Fransisca dan Aliya, 2018 : 677) terkait ISO 9001. Bahwa faktor-faktor yang membentuk ISO 9001 diantaranya berfokus pada pelanggan, kepemimpinan, terlibatnya sumber daya manusia, proses yang melalui berbagai pendekatan, perbaikan yang selalu berkelanjutan, fakta-fakta yang menjadi dasar diambilnya keputusan, serta hubungan dengan para pihak yang berkepentingan. Ketika diuji dengan para stakeholders menunjukkan hasil korelasi rata-rata di atas 0.870. Hal ini berarti faktor-faktor yang membentuk ISO 9001 ini telah berhasil menggambarkan dengan jelas tujuan dari ISO 9001.

Penulis meyakini bahwa rangkaian penelitian ini akan memberikan gambaran bahwa adanya ISO 9001 akan membantu pihak entitas menjadi lebih baik lagi. Dan 
dalam arah entitas menuju proses akreditasi tipe B, ISO 9001 akan menjadi faktor pendukung tercapainya tujuan tersebut. Dan hasil penelitian ini diharapkan akan memberikan kepuasan tidak hanya bagi pihak internal entitas tetapi juga bagi pihak eksternal entitas, bahwa ISO 9001 memberikan banyak manfaat bagi pihak RSUD Kayu Agung Kabupaten OKI.

\section{KESIMPULAN}

Berdasarkan hasil penelitian dapat disimpulkan bahwa terdapat hubungan sebesar 62.9\% antara Audit Mutu Internal ISO 9001 terhadap Sistem Manajemen RSUD Kayu Agung Kabupaten Ogan Komering Ilir. Bayangkara (2016:40) memiliki pendapat yang sama dengan hasil penelitian ini.Mewakili audit mutu internal ini dapat dilakukan dari faktor-faktor seperti berfokus pada pelanggan, kepemimpinan, keterlibatan SDM, pendekatan proses, perbaikan berkelanjutan, pembuatan keputusan berdasarkan fakta, serta hubungan dengan pemangku kepentingan. Korelasi dari hasil pengujian menunjukkan hasil yang sangat memadai. Maka kita bisa meyakini kesemua faktor ini jika sebuah entitas jenis manapun mampu mewujudkan dengan maksimal, bukan tidak mungkin kualitas terbaiklah yang akan dihasilkan.

\section{SARAN}

Hasil penelitian ini dapat menjadi informasi bahwa sistem manajemen RSUD Kayu Agung Kabupaten Ogan Komering Ilir dapat dipengaruhi oleh audit mutu internal ISO 9001. Penerapan standar ini sangat membantu tercapainya tujuan visi misi sebuah entitas. Penerapan terhadap standar ini harusnya dapat ditiru oleh instansiinstansi lainnya. Selain itu, pengembangan terhadap penelitian ini diharapkan dapat menambah variabel-variabel lain yang kiranya mempengaruhi sistem manajemen sebuah entitas.

\section{DAFTAR PUSTAKA}

Agoes, Sukrisno. 2014. Auditing Petunjuk Praktis Pemeriksaan Akuntan oleh Akuntan Publik Edisi ke 4 Buku 1. Jakarta: Penerbit Salemba Empat.

Bayangkara, IBK. 2016. Audit Manajemen Prosedur dan Implementasi Edisi 2. Jakarta: Penerbit Salemba Empat. 
Fransisca, Septiani; dan Aliya, Sabeli. 2018. Analisis Faktor Audit Mutu Internal ISO 9001:2015. Malang: Prosiding Seminar Nasional dan Call For Paper Manajemen, Akuntansi, dan Perbankan, Volume 1, Nomor 1, Oktober.

Lo, Eko Widodo. 2012. Pengaruh Tingkat Kesulitan Keuangan terhadap Manajemen Laba: Teori Keagenan Versus Teori Signaling. Yogyakarta: Universitas Kristen Duta Wacana, Jurnal Riset Akuntansi dan Keuangan, Volume 8, Nomor 1, Februari. Mulyadi. 2016. Sistem Akuntansi. Jakarta: Penerbit Salemba Empat.

Priyadi, Gilang. 2012. Panduan Audit Sistem Mutu. Jakarta: Penerbit Bumi Aksara.

Sugiyono. 2014. Metode Penelitian Kuantitatif Kualitatif dan RED. Bandung: Penerbit Alfabeta.

Sujarweni, V.Wiratna. 2016. Kupas Tuntas Penelitian Akuntansi dengan SPSS. Yogyakarta: Penerbit Pustaka Baru Press.

Suryatama, Erwin. 2014. Aplikasi ISO Sebagai Standar Mutu. Jakarta: Penerbit Kata Pena. 